\title{
A frágil confiabilidade do tribunal de contas de Santa Catarina na fiscalização dos recursos da educação: governo estadual deixou de aplicar mais de $R \$ 2,1$ bilhões em educação de 1998 a 2008 mas TC aprovou as contas estaduais
}

\section{Nicholas Davies*}

\section{Resumo}

O estudo examinou procedimentos adotados pelo Tribunal de Contas de Santa Catarina para a verificação da receita e despesa em educação, com base em seus relatórios sobre as contas estaduais de 1998 a 2008, e chegou a vários resultados, alguns indicados a seguir. Entre os aspectos positivos cabe ressaltar (1) o registro da ilegalidade e inconstitucionalidade do governo estadual em subtrair impostos da educação e saúde através de mecanismos de desvinculação, como o SEITEC e o Fundo Social e (2) o descumprimento de várias exigências constitucionais e legais. Entre os pontos negativos cabe destacar (1) a provável confusão entre gastos na função orçamentária Educação (definida pela Lei oํ 4.320) e em MDE (definida pelos artigos 70 e 71 da LDB, (2) a aceitação da contabilização das despesas educacionais por órgáos diferentes, contrariando o que estabelece a LDB, (3) a oscilação nos critérios de despesas, ora empenhadas, ora liquidadas, ora pagas, e (4) a falta de uma posição firme sobre a inclusão dos inativos no cálculo das despesas legais em MDE, adotando dois cálculos (com e sem inativos), mas na prática contabilizando os inativos no cálculo do percentual mínimo. A debilidade maior do TC, no entanto, foi o fato de ele, apesar de ter constatado que o governo estadual náo aplicou o percentual mínimo (25\%) dos impostos em educação, nem os $15 \%$ dos impostos no ensino fundamental, nem a receita do Fundef, não emitiu parecer prévio contrário à aprovaçáo das contas estaduais, limitando-se a fazer ressalvas e recomendaçôes, quase sempre descumpridas pelo governo estadual, o que levanta a questão sobre a utilidade do TC.

Palavras-chave: Financiamento da educação. Tribunal de Contas. Santa Catarina.

* Doutor em Sociologia pela Universidade de São Paulo. Professor da Faculdade de Educação da Universidade Federal Fluminense, Niterói, RJ. 


\section{Introdução}

Este artigo examina alguns procedimentos adotados pelo Tribunal de Contas (TC) de Santa Catarina na apreciação da aplicação dos recursos vinculados à educação nas contas estaduais de 1998 a 2008, numa pesquisa ${ }^{1}$ que envolve todos os Tribunais de Contas (TCs) do Brasil nesta verificaçấo. Foi suscitada pela experiência do autor na análise da aplicação da verba da educação por governos estadual e municipais do Rio de Janeiro e na sua fiscalizaçáo por parte do TC do Estado do Rio de Janeiro (DAVIES, 2000, 2001a) que revelou, entre outras coisas, que a interpretação dos TCs sobre as receitas e despesas vinculadas à manutenção e desenvolvimento do ensino (MDE) nem sempre coincide com o que parece estar na letra e espírito da lei. Isso é importante porque os governos estaduais e municipais procuram seguir (quando o fazem, é claro) as orientaçôes dos TCs na sua prestação de contas e não necessariamente as disposiçóes da Lei de Diretrizes e Bases da Educação Nacional (LDB) (BRASIL, 1996a) ou de pareceres e resoluçôes do Conselho Nacional de Educação (CNE). Daí a importância do estudo dessas interpretaçóes para a avaliação menos imprecisa dos recursos vinculados à MDE.

Esta pesquisa foi iniciada em 1998 (DAVIES, 2001b) e procurou obter as normas editadas pelos TCs desde a Lei Federal no 7.348, de 1985 (BRASIL, 1985), que regulamentou a Emenda Constitucional no 24 (conhecida como Emenda Calmon), de 1983 (BRASIL, 1983), restabelecendo a vinculação de recursos para a educação, eliminada pela Constituição imposta pela ditadura militar em 1967 (BRASIL, 1967). A Lei no 7.348 (BRASIL, 1985) foi tomada como marco inicial porque desde 1967 não havia vinculação constitucional de recursos (restabelecida apenas para os municípios pela Emenda Constitucional nำ, de 1969 (BRASIL, 1969) e porque ela vigorou integralmente até dezembro de 1996 (quando foi promulgada a LDB) e parcialmente a partir de janeiro de 1997, segundo a interpretação dada pelo Parecer no 26, de 1997, do CNE (BRASIL, 1997). Basicamente, esta Lei no 7.348 (BRASIL, 1985) foi importante porque definiu as receitas e despesas vinculadas à $\mathrm{MDE}$, conceito que mereceu uma definição menos elástica 
do que a permitida pela função orçamentária de 'Educação e Cultura', prevista na Lei Federal no 4.320, de 1964 (BRASIL, 1964), que normatiza a elaboração e execução de orçamentos públicos. Desde 2001 esta função foi dividida em duas, uma para a educação (designada pelo número 12) e outra para a cultura.

Outras referências legislativas foram as Emendas Constitucionais no 14 (BRASIL, 1996c), que criou o Fundo de Manutenção e Desenvolvimento do Ensino Fundamental e de Valorização do Magistério (Fundef), em setembro de 1996, e no 53 (BRASIL, 2006), que criou o Fundo de Manutenção e Desenvolvimento da Educação Básica e de Valorização dos Profissionais da Educação (Fundeb), em dezembro de 2006, e as Leis nº 9.394 (BRASIL, 1996a) e no 9.424 (BRASIL, 1996b) (que regulamentou o Fundef), ambas de dezembro de 1996, e a no 11.494 (BRASIL, 2007) (que regulamentou o Fundeb).

Basicamente, as informaçóes e documentos que procurei obter junto ao TC foram os seguintes:

a) Legislação federal, estadual ou municipal adotada pelo TC para a averiguação das receitas e despesas vinculadas à educação ou, mais precisamente, à MDE, conforme definida na Lei $\mathrm{n}^{\circ}$ 7.348, de 1985 (BRASIL, 1985), e nos artigos 70 e 71 da LDB (BRASIL, 1996a). Queria saber, por exemplo, o percentual mínimo que o TC considerava correto, no caso de o percentual das Constituiçóes estaduais e leis orgânicas ser superior aos 25\% previstos na Constituição Federal (CF) de 1988 (BRASIL, 1988). Essa indagação foi suscitada pela experiência no Estado do Rio de Janeiro, em que prefeituras cujas leis orgânicas fixavam um valor superior aos $25 \%$ alegavam que o percentual válido era o da CF, não o das leis orgânicas, e contavam com a interpretação favorável do TCE. Além disso, o governo estadual do Rio de Janeiro (na gestáo de Brizola, um governante supostamente sensível à causa da educação) havia obtido em 1993 liminar do Supremo Tribunal Federal suspendendo a eficácia do percentual mínimo de 35\% fixado na Constituição Estadual de 1989 (RIO DE JANEIRO, 1989), o que significou, na prática, a aceitação dos $25 \%$ pelo TCE;

b) Instruções e normas internas elaboradas pelo TC para o cálculo das receitas e despesas vinculadas à MDE desde a Lei $\mathrm{n}^{-} 7.348$ 
(BRASIL, 1985). Tais instruçôes são fundamentais porque os governos estaduais e municipais procuram seguir os procedimentos nelas contidos, não necessariamente a CF (BRASIL, 1988), a Estadual ou a Lei Orgânica ou a legislação educacional;

c) Definição dos impostos que compóem a base de cálculo do percentual mínimo. Queria saber sobretudo se eram computados as multas e juros de mora dos impostos, a receita da dívida ativa de impostos (DAI), sua atualização monetária e as multas e juros de mora sobre a DAI;

d) Contabilização dos ganhos, complementação federal e rendimentos financeiros com o Fundef/Fundeb, receitas do salário-educação, convênios de natureza educacional (merenda e outros) e receitas de serviços prestados por instituiçóes educacionais e operaçóes de crédito para a educação. Eram/são contabilizados como parte do percentual mínimo ou como acréscimos a ele? Este cálculo é importante porque muitas vezes os governos omitem tais receitas ou as incluem na base de cálculo do percentual mínimo, quando o correto é acrescentá-las integralmente ao mínimo;

e) Critérios de cálculo do valor devido em educação: valores nominais ou valores reais ou, em outras palavras, os valores devidos são corrigidos monetariamente? Estes critérios são fundamentais numa época de inflação alta e mesmo após a decretação do Plano Real, em julho de 1994, porque a inflação persistiu, embora relativamente baixa;

f) Definição de despesas consideradas como MDE. É fundamental a clareza sobre essa definiçẫo porque não raro os governos confundem tais despesas com as realizadas na função orçamentária 'Educação e Cultura', modificada para 'Educaçáo' a partir de 2001, mais ampla do que o conceito de MDE, ou com o órgáo responsável pela educação;

g) Critérios de cálculo das despesas em $\mathrm{MDE}$ - valores empenhados, liquidados ou pagos no ano. Essa diferenciação é fundamental porque não é incomum os governos considerarem os valores empenhados como os aplicados no ensino, mas cancelarem uma parte de tais empenhos no exercício seguinte, fraudando, assim, os valores supostamente aplicados no ensino; 
h) Procedimentos adotados pelo TC tendo em vista a implantação obrigatória do Fundef em 1998 e do Fundeb em 2007.

Entendo que as receitas vinculadas à educação são as seguintes:

- no mínimo 25\% (ou o percentual maior previsto em Constituiçóes Estaduais e Leis Orgânicas municipais, conforme estipula a LDB) de todos os impostos (inclusive as multas e juros de mora de impostos, a receita da dívida ativa de impostos e suas multas e juros de mora); mais

- o ganho com o Fundef ou o Fundeb (ou seja, a diferença positiva entre a contribuição para estes fundos e a receita com eles), a complementação federal para os dois fundos e o rendimento financeiro com eles, contabilizáveis como acréscimos ao percentual mínimo; mais

- as receitas integralmente vinculadas à educação (salário-educação, convênios, programas e demais repasses, sobretudo federais, etc., e operaçôes de crédito vinculadas à educação) e os rendimentos financeiros com elas auferidos, também contabilizáveis como acréscimos ao percentual mínimo.

Vale lembrar que as receitas com o Fundef ou o Fundeb não devem ser confundidas com ganhos, os quais só acontecem quando a receita dos governos com estes fundos é superior à sua contribuição para eles. Neste caso, devem ser contabilizados como acréscimos ao percentual mínimo. Porém, quando há perdas (ou seja, quando a receita é inferior à contribuição), elas devem ser contabilizadas dentro do percentual mínimo. Neste cálculo, não entram a complementação federal e o rendimento financeiro com os fundos, sempre contabilizados como acréscimos ao percentual mínimo, mesmo quando há perdas.

As despesas, por sua vez, se vinculam a estas receitas acima, devendo se classificar como MDE, conforme definida nos artigos 70 e 71 da LDB (BRASIL, 1996a). As despesas pagas pelas receitas (c), mesmo classificadas de MDE, não são contabilizáveis no percentual mínimo ou nas receitas adicionais (ganho, complementação e rendimento financeiro) oriundas do Fundef ou Fundeb. As despesas pagas com as receitas (a) e/ou (b) tiveram/ têm as seguintes particularidades: 
- de 1989 até 1996, pelo menos 12,5\% (a metade dos 25\%) da receita (a) deveriam ter sido aplicados pelos Estados, Distrito Federal (DF) e municípios na erradicação do analfabetismo e na universalização do ensino fundamental, conforme determinado pelo Art. 60 do Ato das Disposiçóes Constitucionais Transitórias da CF de 1988 (BRASIL, 1988);

- de 1997 a 2006, pelo menos 15\% (60\% dos 25\%) dos impostos deveriam ter sido aplicados por tais esferas de governo apenas na universalização do ensino fundamental, sendo que $15 \%$ de alguns destes impostos compuseram o Fundef (implantado obrigatoriamente apenas em 1998), dividido entre o governo estadual e prefeituras de cada Estado de acordo com o número de matrículas no ensino fundamental regular, bem como o peso de cada tipo de matrícula ( $1^{\underline{a}}$ a $4^{\underline{a}}, 5^{\underline{a}}$ a $8^{\underline{a}}$, zona urbana, zona rural, educação especial). Da receita com o Fundef, pelo menos $60 \%$ deveriam ter sido destinados à remuneração dos professores (segundo a Emenda Constitucional no14, ver BRASIL, 1996c) ou dos profissionais do magistério (de acordo com a Lei no 9.424 , ver BRASIL, 1996b) em exercício no ensino fundamental;

- entre 1997 e 2006 os impostos restantes (no mínimo 10\%) poderiam ser utilizados em qualquer nível ou modalidade de ensino, com a única exceção dos municípios, que só poderiam aplicá-los no ensino fundamental e na educação infantil, conforme previsto no art. 11 da LDB (BRASIL, 1996a).

- com a implantação do Fundeb (em 2007), constituído de percentuais provisórios de impostos em 2007 e 2008 e definitivos (20\%) a partir de 2009 , as despesas estaduais e municipais pagas pelo percentual mínimo de impostos se dividem em dois grupos. $\mathrm{O}$ primeiro são as do Fundeb: as estaduais só podem ser empregadas no ensino fundamental e médio e suas respectivas modalidades, enquanto as municipais se destinam somente à educação infantil e ensino fundamental e suas respectivas modalidades. Da mesma forma que no Fundef, pelo menos $60 \%$ do Fundeb se destinam à remuneração dos profissionais do magistério em exercício na educação infantil e no ensino fundamental (caso dos municípios) e no ensino fundamental e no ensino médio (caso dos Estados). O 
segundo grupo é formado por dispêndios financiados pela parcela restante dos impostos do Fundeb, ou seja, pelo menos os 5\% de diferença entre a contribuição para o Fundeb (20\%) e o percentual mínimo (25\%, se for este o percentual previsto na Constituição Estadual) e pelo menos os $25 \%$ dos impostos estaduais e municipais que não entram na formação do Fundeb (Imposto de Renda recolhido pelos governos estaduais e municipais, Imposto de Operaçóes Financeiras com Ouro (IOF)-ouro, o Imposto Predial Territorial Urbano (IPTU), o Imposto sobre Serviços - ISS e o Imposto sobre Transmissão de Bens Imóveis (ITBI)). No caso dos municípios, a receita de impostos fora do Fundeb continua sendo vinculada à educação infantil e ao ensino fundamental, conforme previsto no art. 11 da LDB (BRASIL, 1996a).

O estudo se baseou nos relatórios impressos do TC sobre as contas estaduais de 1998, 1999, 2001, 2002, 2003, 2004, 2005 e eletrônicos de 2000, 2006, 2007 e 2008 (SANTA CATARINA, 1999a, 2000a, 2001, 2002, 2003a, 2004, 2005, 2006, 2007a, 2008, 2009). Pretendia incluir o relatório sobre as contas de 2009, porém ele deixa bastante a desejar, sendo uma cópia do relatório fornecido pela Secretaria Estadual de Fazenda, que não menciona supostos gastos com inativos nem as despesas por órgão. Não pude utilizar norma ou instrução do TC sobre a contabilização da receita e despesa em MDE ou sobre o Fundef ou Fundeb, porque até 2010 não a encontrei em seu portal na internet.

Além da introdução, o estudo compóe-se das seguintes partes. A primeira comenta a contabilização da receita da educação, a segunda, as despesas classificadas pelo TC como MDE, a terceira faz uma análise específica sobre o salário-educação. A quarta apresenta e comenta quatro tabelas. Uma informa todas as receitas de impostos e as despesas classificadas pelo TC como MDE entre 1998 e 2008. A seguinte registra a receita de impostos e os $15 \%$ de impostos vinculados ao ensino fundamental de 1998 a 2006. A terceira contém dados sobre a receita e despesa do Fundef e a remuneração destinada aos profissionais do magistério no ensino fundamental. A quarta contém os dados sobre o Fundeb. 


\section{Contabilização da receita}

De modo geral, o TC contabilizou corretamente as receitas vinculadas à educação, ou seja, impostos, as multas e juros de mora de impostos, a dívida ativa de impostos (ou seja, de anos anteriores) (DAI) e as multas e juros de mora da DAI. Entretanto, as multas e juros de mora da DAI só parecem ter sido computadas a partir de 2002. De qualquer modo, não são receitas significativas. As receitas adicionais aos 25\% (salário-educação, convênios etc.) corretamente não foram incluídas pelo TC na base de cálculo do percentual mínimo, que só se baseia nos impostos. A importância das despesas pagas por tais receitas adicionais é mostrada nas contas de 2004, quando elas teriam totalizado mais de R $\$ 80$ milhóes (SANTA CATARINA, 2005, p. 171), sendo o salário-educação a mais importante.

Além disso, o TC demonstrou atenção para mecanismos que subtraíram recursos da educação. Por exemplo, o relatório sobre as contas de 1999 (SANTA CATARINA, 2000a, p. 67) registra que o "governo estadual deixou de registrar R \$ 52,7 milhóes de receita de ICMS, correspondente aos benefícios concedidos às empresas através do PRODEC. Conclui-se que a educação estadual foi prejudicada em R $\$$ 9,8 milhóes.” Embora o relatório não informe sobre o prejuízo para a educação municipal, é provável que isso tenha acontecido também, pois $25 \%$ do ICMS são destinados aos municípios.

Um prejuízo muito maior para a educação (e também para a saúde, o outro setor que conta com a garantia constitucional de um percentual mínimo de impostos para o seu financiamento) teria acontecido de 2005 a 2008 (e talvez em 2009 e 2010), segundo o relatório do TC sobre as contas de 2008 (SANTA CATARINA, 2009), que registra que desde 2005 impostos têm sido desviados da educação e saúde através do Sistema Estadual de Incentivo à Cultura, ao Turismo e ao Esporte (SEITEC) e do Fundo Social. O prejuízo seria causado pelo fato de as empresas poderem recolher uma parte do ICMS aos Fundos Estaduais de Incentivo à Cultura, Turismo e Esporte, em vez de pagar a integralidade do imposto à Secretaria de Fazenda. A consequência é que esta parte do ICMS recolhido para financiar projetos no âmbito de tais fundos não é incluída na base de cálculo do percentual mínimo vinculado à saúde e a educação. O Fundo Social também é financiado por uma parte do ICMS que as empresas recolhem diretamente 
a ele e também não entra no cálculo dos impostos vinculados à saúde e educação. O prejuízo para a saúde e educação foi significativo entre 2005 e 2008. Segundo o TC, os fundos do SEITEC teriam diminuído em R $\$ 91$ milhóes os recursos para a educação e em $\mathrm{R} \$ 43$ milhões para a saúde. Já o Fundo Social teria provocado um prejuízo ainda maior: $\mathrm{R} \$ 163$ milhóes, na educação, e R \$ 78 milhões, na saúde. O prejuízo total provocado pelos dois mecanismos teria sido de $\mathrm{R}$ \$ 254 milhões, na educação, e $\mathrm{R}$ \$ 122 milhões, na saúde (SANTA CATARINA, 2009).

O TC critica estes mecanismos alegando serem inconstitucionais, com base no art. 167, inciso IV da Constituição Federal, que veda:

a vinculação de receita de impostos a órgão, fundo ou despesa, ressalvada a repartição do produto da arrecadação dos impostos a que se referem os arts. 158 e 159, a destinação de recursos para as açôes e serviços públicos de saúde, para a manutenção e desenvolvimento do ensino e para a realização de atividades da administração tributária, como determinado, respectivamente, pelos arts. $198, \$ 2^{\circ}$, 212 e 37, XXII, e a prestação de garantias às operaçóes de crédito por antecipação de receita, previstas no art. $165, \$ 8^{\circ}$, bem como o disposto no $\$ 4^{\circ}$ deste artigo (SANTA CATARINA, 2009, p. 3155, grifo do autor).

O TC frisa que "não encontra respaldo legal a vinculação de receita do ICMS a fundo de fomento à cultura, turismo e esporte" (SANTA CATARINA, 2009, p. 3155).

O TC também critica o fato de o governo estadual contabilizar as receitas destes fundos como contribuições, quando são receitas tributárias, pois têm origem no ICMS. Esta contabilização foi motivo de ressalva pelo TC sobre as contas de 2008 e, segundo o TC, contraria o disposto no art. 11 da Lei Federal no ${ }^{4} .320 / 64$ e no art. 4oㅡ da Lei (estadual) no ${ }^{\circ}$ 13.336/05 (SANTA CATARINA, 2009).

Os municípios também foram prejudicados pelo sistema SEITEC, pois o governo estadual deixou de repassar a eles $\mathrm{R} \$ 121$ milhóes por conta dele no período, resultando num prejuízo de $\mathrm{R} \$ 30$ milhóes (25\%) para a educação. Vale lembrar que os mecanismos do SEITEC e do Fundo Social, 
ao excluírem parte da receita do ICMS, distorceram e diminuíram também o cálculo do montante vinculado ao ensino fundamental (pelo menos 15\% dos impostos), ao Fundef e à remuneração dos profissionais do magistério em exercício no ensino fundamental.

Segundo o TC, esta prática de criação de fundos para desvincular receitas de certos setores,

tem sido frequente na administração pública brasileira, sobretudo nas esferas estaduais, que buscam assim aumentar o poder discricionário do Poder Executivo na aplicaçáo de parte da sua arrecadação, seja pelas diminuiçóes do repasse constitucional aos municípios e da distribuição da receita entre os poderes, Ministério Público e Tribunal de Contas, seja pela exclusão de tais valores da base de cálculo de aplicação mínima em educação e saúde, permitindo assim um maior poder discricionário na aplicação destes recursos que, invariavelmente, são destinados a açôes de alta visibilidade política (SANTA CATARINA, 2009, p. 3166).

\section{A contabilização das despesas}

Esta rubrica apresenta vários problemas. O primeiro é que o TC não define o que entende por manutenção e desenvolvimento do ensino (MDE) nem explica se verifica se os gastos empenhados, liquidados ou pagos se enquadram em MDE ou, ao contrário, na função orçamentária Educação, definida pela Lei no 4.320 (BRASIL, 1964), que não é sinônimo de MDE, definida pelos artigos 70 e 71 da LDB (BRASIL, 1996a). Por exemplo, as despesas com merenda escolar podem ser classificadas na função Educação, porém não em $\mathrm{MDE}$, pois elas (e outras) são excluídas pelo art. $71 \mathrm{da}$ LDB (BRASIL, 1996a). Aliás, o TC não demonstra atenção em nenhum dos relatórios examinados para gastos em merenda, que podem ter sido ilegalmente contabilizados como MDE pelo governo.

Outra fragilidade é a frouxidão terminológica do TC ao usar o verbo "aplicar" com significados muitos diferentes. Ora significa empenhar, ora liquidar, ora pagar, três categorias bastante distintas. 
Uma terceira dificuldade é o fato de os empenhos contabilizados em MDE terem sido dispersos pelos mais variados órgãos, impedindo ou pelo menos dificultando enormemente o controle dos empenhos. A partir de 2004 esta dispersão ficou maior ainda com a distribuição dos recursos por um grande número de secretarias regionais, que não são órgãos específicos da educação e, portanto, podem ter desviado recursos da educação para os mais variados fins. Para se ter uma idéia da importância do montante da educação destinado às Secretarias Regionais, ele foi de $\mathrm{R}$ \$ 127 milhóes em 2005. Vale lembrar que esta dispersão está em desacordo com a LDB (BRASIL, 1996a), que prevê a realização das despesas da educação por secretaria ou órgão específico.

Este descumprimento transparece no relatório sobre as contas de 2004 que mostra a contradição entre as alegaçóes das Secretarias de Educação e da Fazenda sobre o controle do uso dos recursos do salário-educação (SE). Enquanto a de Educação alegava que no exercício de 2004 esta Secretaria não havia aplicado a totalidade do SE porque a Fazenda não repassara o saldo financeiro disponível para suplementar o orçamento de 2005, a de Fazenda diz que os recursos do SE desde 2004 ficaram à disposição da Secretaria de Educação e que em 2005 os valores foram disponibilizados à Secretaria de Educação sempre quando requerido pelo órgão (SANTA CATARINA, 2005, p. 380-381).

Um quarto problema é a confiabilidade dos dados. Um exemplo é o relatório do TC sobre as contas de 2005 que registra uma grande desproporção entre número de matrículas estaduais no ensino fundamental regular (440.714) e no ensino médio regular (236.360) e suas respectivas despesas empenhadas: R \$ 558 milhóes (ensino fundamental) e R \$ 132 milhóes (ensino médio). Se considerarmos que o número de matrículas no ensino médio regular equivale a pouco mais da metade do número de matrículas no ensino fundamental regular, o lógico seria que suas despesas fossem pelo menos ligeiramente superiores à metade das realizadas no ensino fundamental, ou seja, pelo menos $\mathrm{R}$ \$ 280 milhões, e não os $\mathrm{R}$ \$ 132 milhões. Por isso, é provável que estes empenhos no ensino médio tenham sido computados no ensino fundamental para atender à exigência de aplicação dos $60 \%$ dos $25 \%$ dos impostos no ensino fundamental e/ou 60\% do Fundef no pagamento dos professores, conforme previa a Emenda Constitucional no 14 (BRASIL, 1996c), ou profissionais do magistério, conforme estabelecia a Lei oㅜ 9.424, 
que regulamentou o Fundef (BRASIL, 1996b). Isso é mais do que provável porque o TC não demonstrou em seus relatórios ter verificado se os empenhos no ensino fundamental foram realmente neste nível de ensino. Vale lembrar que constatei esta mesma desproporção nos gastos do governo estadual do Rio de Janeiro durante a vigência do Fundef. Outro exemplo de pouca confiabilidade está nos relatórios de 2007 e 2008 (SANTA CATARINA, 2008, 2009) que numa página registram valores empenhados e liquidados, porém na página seguinte os empenhados são designados como liquidados.

A oscilação na contabilização é outro problema adicional. Um exemplo é a exclusão, das despesas do Fundef, das subvenções sociais às Associações de Pais e Professores do Ensino Fundamental (APPs) que supostamente usavam tais recursos para contratar merendeiras e serventes para as escolas. $\mathrm{O}$ argumento do TC, só adotado a partir de 2003, era de que, com base na LDB (BRASIL, 1996a), não eram despesas legais de MDE. Curiosamente, antes de 2003 o TC não apresentara tal argumento, assim como nunca rejeitou as contas estaduais por causa da inclusão do pagamento dos inativos para fins de cálculo das despesas mínimas em MDE. Contraditoriamente, o relator das contas de 2008 aceita que tais subvençóes sejam contabilizadas no cálculo do percentual mínimo (SANTA CATARINA, 2009).

Outro exemplo de oscilação é que em muitos anos se baseou no critério de despesas orçamentárias (as empenhadas no exercício), porém em 2001 tomou como referência o de despesas financeiras (as efetivamente pagas no exercício, que misturavam e, portanto, confundiam despesas do exercício com os restos a pagar (RP) de exercícios anteriores pagos no exercício) (SANTA CATARINA, 2002). A oscilação continuou a partir de 2005, quando o TC decidiu que não iria se basear em valores empenhados, mas sim em valores liquidados, embora desde 2001 a Secretaria do Tesouro Nacional já recomendasse na instrução para a elaboração do relatório resumido da execução orçamentária (BRASIL, 2001) o critério de despesas liquidadas, assim como o Parecer no 26, de 1997, do Conselho Nacional de Educação (BRASIL, 1997). Esta é uma questão importante porque nem todos os empenhos são liquidados, pois podem ser cancelados em exercício posterior. Portanto, não correspondem necessariamente a gastos efetivos. O critério de valores liquidados seria, pois, o mais confiável.

A oscilação também se manifestou na apreciação das contas estaduais por um mesmo conselheiro, Luis Roberto Herbst, que declarou voto 
contrário à aprovação das contas de 2001 (SANTA CATARINA, 2002) afirmando corretamente, com base no relatório do TC, que o governo não aplicara $15 \%$ dos impostos no ensino fundamental, como determinado pela Emenda Constitucional no 14 (BRASIL, 1996c), que havia pago os inativos com o Fundef e depositado os recursos do Fundef e do salário-educação na conta única do Tesouro Estadual, quando o correto seria que tais recursos tivessem conta própria. Contraditoriamente, estas e outras irregularidades foram/continuaram sendo praticadas pelo governo estadual em todos os anos anteriores e posteriores a 2001, mas o conselheiro não reprovou as contas, inclusive quando foi relator das contas.

Um exemplo de oscilação num mesmo documento é a Instrução Técnica no 4, de 1999 (SANTA CATARINA, 1999b), que permite aos municípios gastarem ora no ensino fundamental e pré-escolar, ora no ensino fundamental e educação infantil.

Um quinto problema é que o TC às vezes incluiu nas despesas do exercício os restos a pagar (RP) de exercícios anteriores. Por exemplo, nas contas de 1999 foram contabilizados R \$ 57 milhóes de RP de exercícios anteriores. Nas contas do Fundef de 2001, dos R \$395 milhóes "efetivamente aplicados”, R\$ 381 milhóes são do exercício de 2001 e o restante é de exercícios anteriores. Contraditoriamente, o TC, no relatório sobre as contas de 1999, diz, citando o Manual do Fundef editado pelo MEC, que "despesas de exercícios anteriores, mesmo as de educação, devem ser efetivadas com os recursos do exercício correspondentes, visto que as contas públicas são regidas pelo regime de competência e não de caixa" (SANTA CATARINA, 2000a, p. 79).

Outro problema é não esclarecer se o TC verificou se os profissionais do magistério pagos pelo Fundef eram de fato professores ou profissionais do magistério em exercício no ensino fundamental ou se a nomenclatura abrangia todos os que atuavam no ensino fundamental, não apenas os professores ou profissionais do magistério. A falta de rigor neste controle é demonstrada na versão simplificada das contas de 2002 (SANTA CATARINA, 2003b, p. 37), que se refere ora a professores, ora a profissionais do magistério, além de errar ao dizer que o Fundef recebe $60 \%$ de tudo que for destinado à educação, quando o certo é que a contribuição (não receita) é de $60 \%$ dos $25 \%$ de alguns impostos, ou, em outras palavras, $15 \%$ de alguns impostos, não tudo. 
A seguir comento a contabilização dos inativos no cálculo do percentual mínimo. Quatro razóes justificam o comentário. Uma é que os empenhos ou pagamento (o TC nem sempre esclarece se são valores empenhados ou pagos) dos inativos representaram sempre uma proporção grande de todos os empenhos contabilizados (cerca de 30\% do total em vários anos). De acordo com o relatório sobre as contas de 2008 (SANTA CATARINA, 2009, p. 3034), o governo estadual teria deixado de aplicar R\$ 805 milhóes de 2006 a 2008, se "desconsiderados os valores com os inativos da educação". Outra é que, sem tais empenhos, o percentual contabilizado foi sempre inferior ao mínimo de $25 \%$. Uma terceira é que o TC, embora discordando da contabilização dos inativos no percentual mínimo, nunca rejeitou as contas estaduais, limitando-se a fazer ressalvas e recomendaçóes de exclusão gradativa de tais despesas do total empenhado em MDE. Uma quarta é que os argumentos apresentados sobretudo pelo Executivo e também pelo Ministério Público junto ao TC para justificar a inclusão dos inativos na contabilização de MDE variaram ao longo do tempo, o que pode indicar oportunismo do Executivo e do Ministério Público.

Corretamente, o TC, em vários dos seus relatórios, argumentou que os inativos não podiam ser pagos com os $25 \%$, porque isso estaria em desacordo com a LDB e porque os inativos não recebem "remuneração", conforme previsto no inciso I do artigo 70, mas sim "proventos". Segundo o TC (SANTA CATARINA, 2002, p. 37),

o inciso I do referido artigo (70 da LDB) destaca o termo 'remuneração', não comportando o dispêndio de recursos para pagamento de inativos, que percebem 'proventos'. Além disso, o termo 'remuneração' está acompanhado da expressão 'e aperfeiçoamento', que, por sua vez, encaminha os gastos exclusivamente para os servidores em efetivo exercício, posto que seria desnecessário o aprimoramento desses que não mais laboram em prol da consecução dos objetivos básicos das instituiçôes educacionais.

Esta é uma observação interessante que nunca encontrei em documentos de TCs e que só veio a ser mencionada pela primeira vez pela Secretaria do Tesouro Nacional em seu Manual para Elaboração do Relatório Resumido da Execução Orçamentária editado em 2007 (BRASIL, 2007). 
Aparentemente, o TC não teve uma posição clara e firme sobre isso. Por exemplo, no ofício que me encaminhou no ano de 2000 o então presidente do TCE (conselheiro Salomão Ribas) informou que os inativos não devem ser considerados MDE, porém nas contas municipais de 1997 e 1998 foram aceitos (SANTA CATARINA, 2000b). Também os relatórios do TC sobre as contas estaduais, embora não considerassem inativos como $\mathrm{MDE}$, nunca rejeitaram as contas, só fazendo "recomendaçóes" para sua exclusão gradual. O relatório das contas de 2001 afirma que:

até o momento este Tribunal não tem recomendado a rejeição das contas do Governo do Estado ou feito qualquer ressalva em razão da inclusão das despesas com inativos para apuração do percentual mínimo de $25 \%$ de aplicação de recursos na manutenção e desenvolvimento do ensino. Mas já é tempo de assumir o compromisso para exclusão gradual dessas despesas (SANTA CATARINA, 2002, p. 34).

Posteriormente, o TC várias vezes fez ressalvas semelhantes, mas o governo estadual não demonstrou ter se preocupado muito com elas e com outras também, tanto que reincidiu nas mesmas irregularidades ao longo dos anos. O TC só parece ter sido mais claro e firme na rejeição do pagamento de inativos com recursos do Fundef, embora nunca tenha rejeitado as contas estaduais pelo fato de o governo estadual ter pago inativos com parte das verbas do Fundef.

Em resposta às ressalvas do TC, a Secretaria Estadual de Fazenda apresentou alegaçóes que variaram ao longo do tempo. Para as contas de 1999, alegou que poderia pagar os inativos com o Fundef porque esta permissão constava do Balanço do Primeiro Ano do Fundef, documento do MEC, segundo o qual

os $40 \%$ restantes [do Fundef] devem ser aplicados em outras açóes de manutenção e desenvolvimento do ensino fundamental, como construção, ampliação, conclusão ou reforma de escolas, capacitação de professores, aquisição de material didático e de equipamentos, serviços diversos e pagamento de inativos (SANTA CATARINA, 2000a, p. 409, grifo do autor). 
No caso das contas de 2004 (SANTA CATARINA, 2005), o Executivo discordou da exclusão dos inativos recomendada pelo TC alegando, com a concordância do Ministério Público junto ao TC, que o art. 71 da LDB (BRASIL, 1996a) não menciona inativos na definição do que não é MDE.

O TC, por sua vez, se contrapôs ao Executivo dizendo que a regra da Administração Pública é fazer apenas o que a lei permite, e a LDB (BRASIL, 1996a) não prevê gastos com inativos como MDE. Aliás, o Ministério Público junto ao TC sempre acompanhou a interpretação do Executivo, apresentando, no caso das contas de 2008 (SANTA CATARINA, 2009), um novo "argumento": os gastos com pagamento dos inativos com recursos do Tesouro nada mais são do que obrigações patronais não recolhidas tempestivamente para formação de um fundo previdenciário.

A fragilidade das alegaçóes do governo estadual fica evidente no fato de ele ter aceito excluir 5\% dos gastos dos inativos por ano, ao longo de 20 anos, com base em plano que apresentou ao TC em 2007, conforme consta do relatório do TC sobre as contas de 2007 (SANTA CATARINA, 2008). Ora, se o governo estadual tinha tanta certeza que os inativos podiam ser incluídos na contabilização do mínimo, não fazia sentido ter apresentado um plano de exclusão dos inativos deste cálculo.

De qualquer modo, sem a inclusão do pagamento dos inativos no cálculo dos $25 \%$ pelo governo estadual, o percentual mínimo nunca teria sido cumprido, na suposição, é claro, que o governo não tenha cometido outras ilegalidades, não detectadas pelo TC, que estranhamente nunca rejeitou as contas com base nesta ilegalidade.

\section{O salário-educação}

A propósito do salário-educação (SE), a análise do TC contém pontos positivos e negativos e inconsistências. Um positivo é ele registrar e verificar esta receita e despesa, acompanhamento que muitos TCs não fazem. Um segundo ponto positivo é a crítica que faz ao fato de o governo estadual ter colocado a receita do SE na conta única do Tesouro e náo numa conta separada, própria do SE, impedindo o controle sobre o emprego do SE. Este depósito na conta única do Tesouro pode, por exemplo, ter gerado rendimento financeiro não revertido para financiar o ensino fundamental 
(vinculação legal do SE até o final de 2006, pois desde 2007 ele passou a financiar a educação básica).

Entretanto, esta crítica não se repete em todos os relatórios que analisei. Um exemplo deste rendimento é o obtido nas contas de 2006: $\mathrm{R}$ \$ 3,1 milhóes. Ele deve ter sido significativo sobretudo porque em todos os anos de 1999 a 2006 o governo estadual não empenhou toda a receita. Segundo a publicação Para onde vai o seu dinheiro - contas de 2006, do TC (SANTA CATARINA, 2007b, p. 26), dos R 559 milhóes de receita com o SE de 1999 a 2006, R \$ 77,6 milhóes não teriam sido empenhados, valores que, atualizados monetariamente e acrescidos do provável, porém não declarado rendimento financeiro em todos os exercícios, talvez ultrapassassem R \$ 100 milhôes. Isso até 2006. A não-aplicação do valor devido continuou pelo menos em 2007 e 2008, quando R \$ 24 milhóes e R \$ 8,6 milhóes, respectivamente, deixaram de ser aplicados, segundo o relatório do TC sobre as contas de 2008 (SANTA CATARINA, 2009). Em síntese, até 2008 mais de $\mathrm{R} \$ 130$ milhões (se considerarmos os prováveis rendimentos náo contabilizados) do SE não teriam sido aplicados.

Apesar destes pontos positivos, o TC não demonstra, nos relatórios, ter verificado a aplicação real do SE, baseando-se apenas em dados contábeis, que não correspondem necessariamente a gastos reais nas atividades devidas.

Outro ponto frágil é ele ter cometido vários erros na informação sobre a legislação do SE. Durante vários anos (nos relatórios de 1999 a 2006 pelo menos) informou que as empresas poderiam abater do valor devido em SE os investimentos feitos na educação fundamental de funcionários ou seus dependentes, quando isso só foi permitido até 1996, quando a EC 14 (BRASIL, 1996c) determinou que as empresas deveriam recolher todo o SE ao Fundo Nacional de Desenvolvimento da Educação (FNDE) e que as empresas só poderiam abater tais gastos no caso de funcionários e dependentes que já estivessem cursando o ensino fundamental antes da Lei no 9.424, de 1996 (BRASIL, 1996b).

Outro equívoco presente nos relatórios das contas de 1999 e 2002, por exemplo, foi dizer que o repasse do salário educação é distribuído entre o governo estadual e seus respectivos municípios proporcionalmente ao número de alunos matriculados no ensino fundamental regular. Essa redistribuição é equivalente a pelo menos $50 \%$ do valor da quota estadual, devendo ser regulamentado por lei estadual. 
O correto é repasse da cota estadual do SE e o critério da redistribuição é o número de alunos no ensino fundamental (não ensino fundamental regular). O TC deveria informar que, enquanto não houvesse lei estadual, prevista na Lei federal no 9.766, de 1998 (BRASIL, 1998), regulamentando tal repartição entre estado e municípios, a cota estadual seria totalmente do governo estadual.

Além de equívocos, o TC é inconsistente na interpretação da legislação. Por exemplo, no exame das contas de 2001 (SANTA CATARINA, 2002, p. 40-41), o relator, Wilson Wan-Dall, concordou com a alegação do governo de que não haveria determinação legal para o SE ser aplicado integralmente no mesmo exercício, discordando da ressalva feita pelo corpo técnico. Segundo o relator (SANTA CATARINA, 2002, p. 41),

o parágrafo único do art. $8^{\circ}$ da Lei de Responsabilidade Fiscal estabelece que 'os recursos legalmente vinculados à finalidade específica serão utilizados exclusivamente para atender ao objeto de sua vinculação, ainda que em exercício diverso daquele em que ocorrer o ingresso'. Significa dizer que se os recursos vinculados não puderem ser vinculados em um exercício, podem ser aplicados nos exercícios subseqüentes, mas não podem ter outra destinação pelo fato de que não foram aplicados no exercício em que ingressaram no Tesouro do ente. Assim, o que deve ser verificado é se os recursos financeiros recebidos do salário-educação, e não aplicados, se encontram registrados e disponíveis em contas bancárias específicas e se foram aplicados nos exercícios subsequentes.

Entretanto, no relatório sobre as contas de 2004, outro relator, Otávio Gilson dos Santos (SANTA CATARINA, 2005, p. 259), declarou que

Embora a Lei Complementar no $101 / 00$ não tenha explicitado que os recursos vinculados náo aplicados no exercício devem ser aplicados no exercício seguinte (art. 8o), é indesejável que os recursos financeiros fiquem disponíveis para aplicação nos exercícios seguintes, pois se tratam de recursos vinculados. E 
não se pode admitir que a ausência de aplicação de saldos ultrapasse o exercício seguinte.

Este problema continuou nas contas seguintes (por exemplo, nas de 2008), com o governo alegando não ser obrigado a aplicar a integralidade do SE no exercício em que foi arrecadado, e o TC afirmando que, embora a legislação não mencione a "obrigatoriedade de aplicação no ano, a permanência de tais recursos na formação de superávits financeiros não se justifica, sobretudo perante as deficiências ainda encontradas no ensino público" (SANTA CATARINA, 2009, p. 3259).

\section{Detalhamento e comentários sobre as receitas e despesas estaduais vinculadas à MDE entre 1998 e 2008, ao ensino fundamental e ao Fundef entre 1998 e 2006 e ao Fundeb em 2007 e 2008}

A seguir comento e detalho as quatro tabelas. Para facilitar a visualização e os cálculos, os valores abaixo se referem a $\mathrm{R} \$$ milhóes, salvo quando indicado em contrário ( $\mathrm{R} \$$ bilhóes), e foram arredondados para cima, quando a casa decimal foi superior a 0,5 , ou para baixo, quando inferior a 0,5. As iniciais N.I. (Não Informado) significam que os dados não foram encontrados nos relatórios. Cabe ressaltar que os cálculos foram dificultados pelo fato de o TC nem sempre seguir uma mesma metodologia e/ou fornecer todos os dados.

A tabela 1, apresenta as receitas e despesas estaduais vinculadas à MDE entre 1998 e 2008, e as seguintes observaçóes podem ser feitas com base nos dados nela contidos e/ou nos relatórios do TC em que se baseiam.

- O governo estadual deixou de aplicar R \$2,143 bilhóes em MDE de 1998 a 2008, com base nos dados contidos nos relatórios do TC sobre as contas estaduais (SANTA CATARINA, 1999a, 2000a, 2001, 2002, 2003a, 2004, 2005, 2006, 2007a, 2008, 2009), o que se deve quase que totalmente à inclusão equivocada do pagamento com inativos no cálculo do valor mínimo devido (25\% dos impostos).

- Em 1998 o TC utilizou critérios diferentes de cálculo da despesa. Inicialmente considerou as despesas empenhadas ( $\mathrm{R}$ \$ 658 milhóes) 
e depois as pagas ( $\mathrm{R} \$ 554$ milhóes), sendo que estas últimas excluíram R \$ 181 milhóes de restos a pagar (RP) processados e náo processados de 1998, porém incluíram $\mathrm{R} \$ 78$ milhóes de $\mathrm{RP}$ de exercício anterior pagos em 1998 (SANTA CATARINA, 1999a). $\mathrm{O}$ resultado disso é que os percentuais supostamente aplicados caíram de 32,6\% (no caso de despesas empenhadas, sem os R \$ 78 milhôes de RP) para $27,5 \%$, no caso de despesas pagas, sem os $\mathrm{R} \$$ 181 milhóes de empenhos não pagos, porém com os $\mathrm{R} \$ 78$ milhóes de RP. O relatório deixa a desejar porque não informa os empenhos não pagos no ensino fundamental e no Fundef no exercício, assim como a receita do Fundef destinada à remuneração dos professores ou profissionais do magistério em exercício no ensino fundamental.

Com relação a estes R\$ 181 milhóes de RP de 1998, o estranho é que eles não correspondem à totalidade dos RP pagos em exercícios posteriores (por exemplo, R \$ 57 milhóes em 1999 e R \$ 52 milhóes em 2001) (SANTA CATARINA, 1999a, 2000a, 2002). Por isso, é provável que parte significativa deles tenha sido cancelada em exercícios posteriores e, portanto, deixado de ser aplicada na educação, porém o TC não demonstrou atenção para esta manobra típica dos governos de cancelar empenhos em exercícios posteriores. Foi somente a partir de 2004 (SANTA CATARINA, 2005) que os relatórios do TC passaram a demonstrar atenção para este tipo de manobra e a excluir RP de exercícios anteriores cancelados no exercício. A propósito dos RP de exercícios anteriores pagos no exercício e RP do exercício, vale lembrar que provocaram distorçôes pelo menos em 1999 e 2001 (SANTA CATARINA, 2000a, 2002).

- Outro problema na contabilização em 1998 (e também em 1999, 2000 e 2001) é que o TC se baseou nas despesas pagas, porém em exercícios posteriores tomou como referência as empenhadas (SANTA CATARINA, 1999a, 2000a, 2001, 2002). O relatório de 1998 deixou a desejar porque não informou empenhos ou gastos efetivos com inativos, porém declarou que eles foram incluídos no cálculo das despesas vinculadas ao percentual mínimo (SANTA CATARINA, 1999a). Em 2000 o TC também não informou os empenhos e provavelmente os computou neste cálculo (SANTA CATARINA, 2001). $\mathrm{Na}$ falta de dados precisos sobre os gastos com inativos, optei, com base nos gastos declarados em inativos 
em 1999 e 2001, por fazer uma estimativa de $\mathrm{R} \$ 150$ milhóes em 1998 e R \$ 200 milhóes em 2000.

- Em 1999 foram empenhados R 645 milhōes do exercício, porém o valor "desembolsado" no exercício foi de R $\$ 690$ milhóes, pois incluiu cerca de R \$ 57 milhóes de RP pagos no exercício, mas excluiu cerca de R \$ 13 milhóes de RP de 1999 apenas empenhados. A consequência é uma grande diferença entre o valor empenhado ( $\mathrm{R}$ \$ 645 milhóes) e o valor pago (R \$ 690 milhóes). Vale notar ainda que em 1999 a educação deixou de receber cerca de $\mathrm{R} \$ 10$ milhóes por conta de concessóes a empresas através do PRODEC, conforme informa o TC (SANTA CATARINA, 2000a, p. 69).

- Em 2000 (SANTA CATARINA, 2001) o TC não informou os empenhos com inativos, por mim estimados em $\mathrm{R} \$ 200$ milhóes. Já em outros anos foram informados e excluídos, resultando em empenhos percentuais inferiores aos 25\%, mas isso não levou o TC a rejeitar as contas, mas apenas a fazer ressalvas e recomendaçóes.

- Os relatórios do TC também não esclarecem se os empenhos com subvenções sociais às APPs (Associaçóes de Pais e Professores do Ensino Fundamental) foram excluídos no cálculo dos empenhos em MDE, tal como o TC fez no cálculo dos empenhos com o Fundef a partir de 2003 (SANTA CATARINA, 2004, 2005, 2006, 2007a).

- O relatório sobre as contas de 2002 se baseia apenas em valores empenhados (SANTA CATARINA, 2003). O TC náo informa se $\mathrm{RP}$ de exercícios anteriores foram pagos no exercício e se empenhos de 2002 não foram pagos em 2002, como fez em outros anos.

- O relatório sobre as contas de 2003 não menciona RP do exercício e de exercícios anteriores (SANTA CATARINA, 2004).

- Pelo menos a partir de 2004 o TC demonstrou atenção para o cancelamento de empenhos de RP de exercícios anteriores e passou a excluí-los do cálculo do montante empenhado no exercício (SANTA CATARINA, 2005, 2006, 2007a, 2008, 2009).

- O relatório de 2004 menciona que, se excluídos os restos a pagar de 2003 cancelados em 2004 (R \$ 13 milhóes), o percentual cairia de 29\% para 28,74\%. Náo esclarece se RP de 2003 pagos em 2004 foram contabilizados como gastos em 2004 (SANTA CATARINA, 
2005, p. 172).

- O relatório sobre as contas de 2005 registra que as despesas empenhadas e liquidadas foram, respectivamente, de R\$1,446 bilhão e R \$ 1,434 bilhão, porém o TC, seguindo orientação da STN, deduziu deste valor cerca de R \$ 15 milhóes de RP de 2004 cancelados em 2005, resultando em despesas empenhadas e liquidadas, respectivamente, de $\mathrm{R}$ \$ 1,431 bilhão e $\mathrm{R} \$ 1,419$ bilhão. Sem estes $\mathrm{RP}$ e os R \$ 292 milhóes dos inativos, as despesas empenhadas caem para R\$ 1,139 bilhão (SANTA CATARINA, 2006).

- Em 2006, se excluídos os inativos e os R\$ 18 milhóes de restos a pagar de 2005 cancelados, o percentual não aplicado cai para 20,28\% (SANTA CATARINA, 2007a).

- O relatório do TC sobre as contas de 2007 é inconsistente, pois a p. 149 informa que foi empenhado R \$ 1,215 bilhão (sem os inativos) e liquidado $R$ \$ 1, 172 bilhão, porém a p. 150 registra a liquidação de R\$ 1,215 bilhão (SANTA CATARINA, 2008, p. 149-150). Os $\mathrm{RP}$ cancelados (R\$3,9 milhão) foram excluídos do cálculo, porém não os gastos com os inativos ( $\mathrm{R} \$ 328$ milhóes), com os quais foi possível cumprir a exigência de aplicação do percentual mínimo de 25\% (SANTA CATARINA, 2008).

- Também no relatório sobre as contas de 2008 o TC se contradiz nos dados, informando na folha 3029 (tabela 1.6.1.4) que foi empenhado R \$ 1,470 bilhão e liquidado R \$ 1,449 bilhão, porém na folha seguinte (3030) os valores liquidados passam a ser de $\mathrm{R} \$$ 1,470 bilhão (SANTA CATARINA, 2009, p. 3029-3030). No seu cálculo o TC descontou os RP cancelados ( $\mathrm{R}$ \$ 31 milhóes), porém se contradisse com o que havia feito nos relatórios de 2003 a 2006, quando excluiu os gastos nas APPs (Associaçóes de Pais e Professores) por considerá-los subvençóes sociais. A alegaçáo do conselheiro-relator (Salomão Ribas Júnior) foi de que, não obstante a LDB prever que as subvençóes

não podem ser consideradas como manutenção e desenvolvimento do ensino, este Tribunal tem entendido que tais valores podem ser considerados como tal, sendo que o único problema consiste na 
forma de pagamento, o que não inviabiliza que tais valores sejam computados para apuraçáo do percentual mínimo (SANTA CATARINA, 2009, p. 3032).

Se excluíssemos os R \$ 63 milhóes gastos com tais subvenções, o valor aplicado (sem os inativos) cairia para $\mathrm{R} \$ 1,585$ bilhão.

\section{TABELA 1 - Receita e despesa estadual de Santa Catarina vinculada à MDE de 1998 a 2008}

\begin{tabular}{|c|c|c|c|c|c|c|c|c|}
\hline Ano & $\begin{array}{l}\text { Receita } \\
\text { líquida de } \\
\text { impostos, } \\
\text { (A) }\end{array}$ & $\begin{array}{c}\% \\
\text { mínimo } \\
\text { dos imp. } \\
(25 \%) \text {, } \\
\text { (B) }\end{array}$ & $\begin{array}{l}\text { Desp. e \% } \\
\text { empenhado, } \\
\text { (C) }\end{array}$ & $\begin{array}{l}\text { Empenho } \\
\text { c/ inativos, } \\
\text { (D) }\end{array}$ & $\begin{array}{l}\text { RP de } \\
\text { exercícios } \\
\text { anteriores } \\
\text { contab. } \\
\text { pelo TC, } \\
\text { (E) }\end{array}$ & $\begin{array}{c}\text { Desp. e \% emp. } \\
\text { ou paga (sem } \\
\text { inativos e RP } \\
\text { cancelados) (cál- } \\
\text { culo do TC) } \\
\text { (F) }\end{array}$ & $\begin{array}{c}\text { Desp. e \% } \\
\text { emp. (sem ina- } \\
\text { tivos e RP de } \\
\text { exercícios ante- } \\
\text { riores) (meus } \\
\text { cálculos), } \\
(\mathrm{G})=(\mathrm{C}-\mathrm{D}-\mathrm{E})\end{array}$ & $\begin{array}{c}\text { Desp. emp. a } \\
\text { maior ou me- } \\
\text { nor do mínimo } \\
\text { devido (meus } \\
\text { cálculos), } \\
(\mathrm{H})=(\mathrm{G}-\mathrm{B})\end{array}$ \\
\hline 1998 & $2,015 \mathrm{bi}$ & 504 & $\begin{array}{c}658 \\
(32,6 \%)\end{array}$ & $\begin{array}{l}\text { N.I. (150 } \\
\text {-estim.) }\end{array}$ & 78 & $\begin{array}{c}554(27,5 \%) \\
\text { Paga }\end{array}$ & $430(20,9 \%)$ & -74 \\
\hline 1999 & $2,254 \mathrm{bi}$ & 563 & $\begin{array}{c}645 \\
(28,6 \%)\end{array}$ & 193 & 57 & N.I. & $395(17,5 \%)$ & -168 \\
\hline 2000 & $2,685 \mathrm{bi}$ & 671 & $\begin{array}{c}702 \\
(26,1 \%)\end{array}$ & $\begin{array}{c}\text { N.I. (200 - } \\
\text { estim.) }\end{array}$ & N.I. & N.I. & $502(18,7 \%)$ & -169 \\
\hline 2001 & 3,115 bi & 779 & $\begin{array}{c}867 \\
(27,8 \%)\end{array}$ & 257 & 53 & $610(19,5 \%)$ & $557(17,9 \%)$ & -222 \\
\hline 2002 & $3,681 \mathrm{bi}$ & 920 & $\begin{array}{l}1,089 \mathrm{bi} \\
(29,5 \%)\end{array}$ & 305 & N.I. & N.I. $(21,3 \%)$ & $784(21,3 \%)$ & -136 \\
\hline 2003 & $4,407 \mathrm{bi}$ & $1,102 \mathrm{bi}$ & $\begin{array}{c}1,279 \text { bi } \\
(29 \%)\end{array}$ & 348 & N.I. & N.I. $(21,1 \%)$ & $931(21,1 \%)$ & -171 \\
\hline 2004 & 4,846 bi & $1,211 \mathrm{bi}$ & $\begin{array}{c}1,406 \text { bi } \\
(29 \%)\end{array}$ & 372 & N.I. & N.I. $(21,3 \%)$ & $\begin{array}{l}1,034 \mathrm{bi} \\
(21,3 \%)\end{array}$ & -177 \\
\hline 2005 & $5,490 \mathrm{bi}$ & $1,373 \mathrm{bi}$ & $\begin{array}{l}1,446 \mathrm{bi} \\
(26,3 \%)\end{array}$ & 292 & N.I. & N.I. & $\begin{array}{c}1,154 \text { bi } \\
(21 \%)\end{array}$ & -219 \\
\hline 2006 & 5,885 bi & $1,471 \mathrm{bi}$ & $\begin{array}{l}1,628 \mathrm{bi} \\
(27,6 \%)\end{array}$ & 435 & N.I. & $\begin{array}{l}1,193 \mathrm{bi} \\
(20,2 \%)\end{array}$ & $\begin{array}{l}1,193 \mathrm{bi} \\
(20,2 \%)\end{array}$ & -278 \\
\hline 2007 & 6,603 bi & $1,651 \mathrm{bi}$ & $\begin{array}{l}1,692 \mathrm{bi} \\
(25,6 \%)\end{array}$ & 328 & N.I. & $\begin{array}{l}1,364 \mathrm{bi} \\
(20,6 \%)\end{array}$ & $\begin{array}{l}1,364 \mathrm{bi} \\
(20,6 \%)\end{array}$ & -287 \\
\hline 2008 & $7,554 \mathrm{bi}$ & $1,888 \mathrm{bi}$ & $\begin{array}{l}1,940 \mathrm{bi} \\
(25,6 \%)\end{array}$ & 292 & N.I. & $\begin{array}{l}1,648 \mathrm{bi} \\
(21,8 \%)\end{array}$ & $\begin{array}{c}1,648 \\
(21,8 \%)\end{array}$ & -242 \\
\hline Total & & & & & & & & $-2,143 \mathrm{bi}$ \\
\hline
\end{tabular}

Fonte: Relatórios do TC sobre contas estaduais (SANTA CATARINA, 1999a, 2000a, 2001, 2002, 2003a, 2004, 2005, 2006, 2007a, 2008, 2009) e cálculos efetuados pelo autor. 
A tabela 2, a seguir, mostra que, com base nos relatórios do TC, o governo estadual deixou de empenhar $\mathrm{R} \$ 631$ milhóes legalmente devidos no ensino fundamental de 1998 a 2006. É provável que o valor seja até maior porque os empenhos não pagos num exercício não são quitados necessariamente em exercícios posteriores, podendo ser cancelados, e porque os relatórios não informaram os dispêndios com inativos no ensino fundamental em quatro anos (de 1998 a 2001) que, se excluídos, aumentariam os valores não empenhados entre 1998 e 2006.

TABELA 2 - Receita e despesa estadual vinculada ao ensino fundamental (EF) de 1998 a 2006 (mínimo de 60\% de 25\% dos impostos, ou 15\%)

\begin{tabular}{|c|c|c|c|c|c|c|c|c|}
\hline Ano & $\begin{array}{c}25 \% \text { da } \\
\text { receita } \\
\text { líquida dos } \\
\text { impostos, } \\
\text { (A) }\end{array}$ & $\begin{array}{c}\text { Despesa míni- } \\
\text { ma devida no } \\
\text { EF (15\% dos } \\
\text { impostos, } \\
\text { (B) }\end{array}$ & $\begin{array}{c}\text { Desp. e \% emp. } \\
\text { no EF (inclui } \\
\text { inativos e perdas } \\
\text { com Fundef, } \\
\text { (C) }\end{array}$ & $\begin{array}{l}\text { Emp. com } \\
\text { inativos } \\
\text { no EF, se } \\
\text { informado, } \\
\text { (D) }\end{array}$ & \begin{tabular}{|c} 
Emp. a maior \\
ou menor no \\
EF (inclui \\
inativos, se \\
informado), \\
$(\mathrm{F})=(\mathrm{C})-(\mathrm{B})$ \\
\end{tabular} & \begin{tabular}{|} 
Emp. no EF \\
$($ sem inat.) \\
$(G)=(C)-(D)$
\end{tabular} & \begin{tabular}{|c|} 
Emp. a \\
maior ou \\
menor no \\
EF (sem \\
inativos), \\
$(\mathrm{H})$ \\
\end{tabular} & $\begin{array}{c}\% \text { dos } \\
25 \% \\
\text { emp. no } \\
\text { EF (sem } \\
\text { inativos), } \\
\text { (I) } \\
\end{array}$ \\
\hline 1998 & 504 & 302 & $260(51,6 \%)$ & N.I. & -42 & N.I. & N.I. $(-42)$ & N.I. \\
\hline 1999 & 563 & 338 & $248(44 \%)$ & N.I. & -90 & N.I. & N.I. $(-90)$ & N.I. \\
\hline 2000 & 671 & 403 & $328(48,8 \%)$ & N.I. & -75 & N.I. & N.I. $(-75)$ & N.I. \\
\hline 2001 & 779 & 467 & $351(45,1 \%)$ & N.I. & -116 & N.I. & N.I. $(-116)$ & N.I. \\
\hline 2002 & 920 & 552 & $639(69,4 \%)$ & 153 & 87 & 487 & -65 & $52,8 \%$ \\
\hline 2003 & $1,102 \mathrm{bi}$ & 661 & $711(64,5 \%)$ & 130 & 50 & 581 & -80 & $52,7 \%$ \\
\hline 2004 & $1,211 \mathrm{bi}$ & 727 & $829(68,4 \%)$ & 141 & 102 & 688 & -39 & $56,7 \%$ \\
\hline 2005 & $1,373 \mathrm{bi}$ & 823 & $889(64,7 \%)$ & 111 & 66 & 778 & -45 & $56,7 \%$ \\
\hline 2006 & $1,471 \mathrm{bi}$ & 883 & $965(65,6 \%)$ & 161 & 82 & 804 & -79 & $54,6 \%$ \\
\hline Total & & & & & & & $-631 \mathrm{mi}$ & \\
\hline
\end{tabular}

Fonte: Relatórios do TC sobre contas estaduais (SANTA CATARINA, 1999a, 2000a, 2001, 2002, 2003a, 2004, 2005, 2006, 2007a) e cálculos efetuados pelo autor (exceto os da coluna "F" e "I").

A tabela 3 (receitas e despesas estaduais do Fundef de 1998 a 2006), a seguir, mostra o seguinte:

- O governo estadual teria deixado de empenhar cerca de $\mathrm{R} \$ 701$ milhóes devidos do Fundef.

- O relatório do TC sobre as contas de 1998 (SANTA CATARINA, 1999a, p. 179) registra que em 1998 a Secretaria Estadual de Fazenda teria assumido o controle do Fundef, no lugar do conselho estadual. É estranho que em nenhum outro relatório o TC volte 
a comentar sobre a existência e/ou o funcionamento do Conselho Estadual do Fundef.

- Conforme comentado acima (sobre a tabela 1), um dos problemas da contabilização é que o TC em vários anos se baseou em valores pagos e em outros em valores empenhados. Por exemplo, o relatório de 1998 registra que, dos $\mathrm{R} \$ 264$ milhóes de receita do Fundef, R\$ 153 milhóes foram "desembolso efetivo", o que, presumivelmente, significa que foram pagos (SANTA CATARINA, 1999a). Em 1999 os empenhos (R \$ 307 milhóes) foram superiores à receita ( $\mathrm{R} \$ 299$ milhóes), o que significa a inclusão de empenhos de exercício anterior, distorcendo obviamente o cálculo das receitas e despesas orçamentárias (SANTA CATARINA, 2000a). Entretanto, os empenhos pagos foram de R\$ 299 milhóes, sendo o saldo inscrito em RP. O mesmo problema pode ser constatado no relatório sobre as contas de 2001 do Fundef que incluem cerca de R \$ 14 milhóes de RP de exercício anterior (SANTA CATARINA, 2002). Em 2001 o valor aplicado do Fundef teria sido de R\$ 395 milhóes, embora o montante empenhado tenha sido de $\mathrm{R} \$ 380$ milhóes, discrepância que se deve ao fato de o TC contabilizar como gastos do exercício R\$ 27 milhóes de RP a pagar de exercício anterior, embora tenha excluído R \$ 13 milhóes de empenhos de 2001 não pagos no exercício (SANTA CATARINA, 2002).

- Ao contrário do que fez a partir de 2002, o TC não excluiu a subvenção concedida às Associaçóes de Pais e Professores (APPs) em 1998, 1999, 2000 e 2001. Por isso, não excluí esta subvenção no cálculo destes anos.

- Pelo menos no relatório sobre as contas de 2006 o TC adota procedimento contraditório ao incluir o gasto com os inativos (R\$ 46 milhôes) no cálculo do montante empenhado "aplicado" do Fundef ( $\$ 580$ milhóes). 
TABELA 3 - Receita e despesa empenhada no Fundef e na remuneração do magistério do ensino fundamental - governo estadual de Santa Catarina

\begin{tabular}{|c|c|c|c|c|c|c|c|c|c|}
\hline Ano & $\begin{array}{l}\text { Receita } \\
\text { do } \\
\text { Fundef } \\
\text { (inclui } \\
\text { rend. } \\
\text { financ.) }\end{array}$ & $\begin{array}{l}\text { Emp. do } \\
\text { Fundef } \\
\text { (inclui } \\
\text { inativos, } \\
\text { se infor- } \\
\text { mado) } \\
\end{array}$ & \begin{tabular}{|c|} 
Emp. do \\
Fundef \\
só com \\
inativos, se \\
informado
\end{tabular} & $\begin{array}{l}\text { Emp. } \\
\text { do } \\
\text { Fundef } \\
\text { com } \\
\text { APPs }\end{array}$ & $\begin{array}{c}\text { Emp. do } \\
\text { Fundef (sem } \\
\text { inativos, } \\
\text { restos a pagar } \\
\text { e APPs) (meus } \\
\text { cálculos) }\end{array}$ & \begin{tabular}{|c} 
Emp. a \\
maior ou \\
menor (meus \\
cálculos, \\
exceto em \\
1998 e 2003)
\end{tabular} & $\begin{array}{c}\text { Desp. e \% } \\
\text { emp. ou paga do } \\
\text { Fundef na re- } \\
\text { mun. dos profis. } \\
\text { do magistério } \\
\text { no EF }\end{array}$ & $\begin{array}{l}\text { Emp. devido } \\
\text { na remun. } \\
\text { (mínimo } \\
\text { de } 60 \% \text { do } \\
\text { Fundef) }\end{array}$ & $\begin{array}{c}\text { Emp. a } \\
\text { maior ou } \\
\text { menor } \\
\text { na } \\
\text { remun. }\end{array}$ \\
\hline 1998 & 264 & 153 & N.I. & 21 & N.I. & $-111(\mathrm{TC})$ & N.I. & 158 & N.I. \\
\hline 1999 & 299 & 307 & 87 & 22 & 220 & -87 & N.I. & 184 & N. I. \\
\hline 2000 & 345 & 328 & 50 & N.I. & 278 & -67 & N. I. & 207 & N. I. \\
\hline 2001 & 397 & 381 & 74 & 26 & 307 & -90 & $\begin{array}{c}211 \text { - paga } \\
(53 \%)\end{array}$ & 238 & -27 \\
\hline 2002 & 448 & 485 & 83 & 29 & 373 & -75 & $258(57,5 \%)$ & 269 & -11 \\
\hline 2003 & 508 & 460 & N.I. & 33 & 426 & $-82 \mathrm{TC}$ & $295(58 \%)$ & 305 & -10 \\
\hline 2004 & 560 & 550 & N.I. & 40 & 510 & -50 & $301(53,8 \%)$ & 336 & -35 \\
\hline 2005 & 621 & 617 & N.I. & 36 & 581 & -40 & $371(59,7 \%)$ & 372 & -1 \\
\hline 2006 & 633 & 580 & 46 & 52 & 534 & -99 & $441(70 \%)$ & 380 & +61 \\
\hline Total & & & & & & $-701 \mathrm{mi}$ & & & \\
\hline
\end{tabular}

Fonte: Relatórios do TC sobre contas estaduais (SANTA CATARINA, 1999a, 2000a, 2001, 2002, 2003a, 2004, 2005, 2006, 2007a) e cálculos efetuados pelo autor.

A tabela 4 (receita e despesa do Fundeb), a seguir, revela que:

- Os dados do Fundeb em 2007 são inconsistentes (SANTA CATARINA, 2008). Enquanto a p. 155 informa que foram empenhados R \$ 785 milhóes e liquidados R 755 milhóes, a p. 156 registra que os valores liquidados foram de $\mathrm{R} \$ 785$ milhóes (SANTA CATARINA, 2008, p. 156). O relatório não informa gastos com as APPs, como o fez em exercícios anteriores. Vale lembrar que dos R \$ 63 milhóes do Fundeb náo aplicados em 2007, no primeiro trimestre de 2008, conforme permitido pela Lei $\mathrm{n}^{\mathrm{o}}$ 11.494 (BRASIL, 2007), apenas R \$ 23 milhóes foram empenhados e um valor menor ainda, $\mathrm{R} \$ 2$ milhóes, foram liquidados.

- Em 2008 foi empenhado R\$ 1,086 bilhão e liquidado R\$ 1,071 bilhão (SANTA CATARINA, 2009). Para o cálculo do valor devido (o R \$ 1,098 bilhão de receita), o TC se baseou no valor empenhado e não no liquidado, como era sua determinação desde 2005 e também é a dos manuais da Secretaria do Tesouro Nacional. $\mathrm{O}$ relatório do TC registra que de 2006 a $2008 \mathrm{R} \$ 121$ milhóes deixaram de ser aplicados no Fundef (em 2006) e no Fundeb (2007 
e 2008) (SANTA CATARINA, 2007a, 2008, 2009). O relatório náo registra inativos pagos com o Fundeb nem RP cancelados pagos no exercício.

TABELA 4 - Receita e despesa empenhada no Fundeb e na remuneração dos profissionais do magistério da educação básica - governo estadual de Santa Catarina

\begin{tabular}{c|c|c|c|c|c|c|c|c|c}
\hline Ano & $\begin{array}{c}\text { Receita } \\
\text { do } \\
\text { Fundeb } \\
\text { (inclui } \\
\text { rend. } \\
\text { financ.) }\end{array}$ & $\begin{array}{c}\text { Emp. do } \\
\text { Fundeb } \\
\text { (nclui } \\
\text { inativos, se } \\
\text { informado) }\end{array}$ & $\begin{array}{c}\text { Emp. do } \\
\text { Fundeb } \\
\text { só com } \\
\text { inativos, se } \\
\text { informado }\end{array}$ & $\begin{array}{c}\text { Emp. do } \\
\text { Fundeb } \\
\text { com } \\
\text { APPs }\end{array}$ & $\begin{array}{c}\text { Emp. do } \\
\text { Fundeb (sem } \\
\text { inativos, } \\
\text { restos a pagar } \\
\text { e APPs) (meus } \\
\text { cálculos) }\end{array}$ & $\begin{array}{c}\text { Emp. a } \\
\text { maior ou } \\
\text { menor } \\
\text { (meus }\end{array}$ & $\begin{array}{c}\text { Desp. e \% } \% \\
\text { emp. do Fun- } \\
\text { deb na remun. } \\
\text { dos prof. do } \\
\text { magistério } \\
\text { no EF }\end{array}$ & $\begin{array}{c}\text { Emp. } \\
\text { devido na } \\
\text { remun. } \\
\text { (mínimo } \\
\text { de 60\% do } \\
\text { Fundef) }\end{array}$ & $\begin{array}{c}\text { Emp. a } \\
\text { maior ou } \\
\text { menor na } \\
\text { remun. dos } \\
\text { prof. do } \\
\text { magistério }\end{array}$ \\
\hline 2007 & 848 & 785 & N.I. & N.I. & 785 & -63 & $557(65,8 \%)$ & 508 & +49 \\
\hline 2008 & 1,098 bi & 1,086 bi & N.I. & N.I. & N.I. & ? & $792(72 \%)$ & 658 & +134 \\
\hline
\end{tabular}

Fonte: Relatórios do TC sobre contas estaduais (SANTA CATARINA, 2008, 2009) e cálculos efetuados pelo autor.

\section{Conclusões}

O estudo demonstrou, com base nos relatórios do TC sobre as contas estaduais de 1998 a 2008 (SANTA CATARINA, 1999a, 2000a, 2001, 2002, 2003a, 2004, 2005, 2006, 2007a, 2008, 2009), que o governo estadual cometeu uma série de irregularidades, a saber: (a) não aplicou o percentual mínimo (25\%) dos impostos em MDE entre 1998 e 2008, deixando de empenhar e/ou pagar $\mathrm{R} \$ 2,143$ bilhóes, se excluído o pagamento dos inativos do cálculo; (b) não despendeu os 15\% dos impostos de 1998 a 2006 no ensino fundamental, conforme exigido pela Emenda Constitucional no 14 (BRASIL, 1996c), totalizando R \$ 631 milhóes a menos do devido legalmente; (c) não empenhou a receita total do Fundef em nenhum ano de 1998 a 2006, totalizando R \$ 701 milhões a menos do devido; (d) não investiu em quase nenhum ano de 1998 a 2006 os 60\% do Fundef na remuneração dos professores ou profissionais do magistério no ensino fundamental; (e) não manteve os recursos do Fundef e também do salário-educação numa conta própria, como exigido por lei, optando por transferi-los para a conta única do Tesouro Estadual; (f) em nenhum ano de 1998 a 2008 empenhou toda a receita do salário-educação, acumulando um total não empenhado superior a R \$ 130 milhóes no período. Apesar de 
constatar uma série de irregularidades e ilegalidades das contas do governo estadual, em nenhum momento emitiu parecer prévio contrário à aprovação das contas, limitando-se a fazer ressalvas e recomendaçóes, quase sempre descumpridas pelo governo estadual, como a de exclusão gradativa do gasto com inativos no cálculo do percentual mínimo.

$\mathrm{O}$ estudo demonstrou ainda alguns aspectos positivos e negativos nos procedimentos do TC para a contabilização da receita e despesa em educação. Entre os positivos cabe ressaltar (a) o registro da ilegalidade e inconstitucionalidade do governo estadual em subtrair impostos da educação e saúde através de mecanismos de desvinculação, como o SEITEC e o Fundo Social, (b) o descumprimento de várias exigências constitucionais e legais, apontadas acima. Entre os pontos negativos cabe destacar (a) a provável confusão entre gastos na função orçamentária Educação, definida pela Lei no 4.320 (BRASIL, 1964) e em MDE, especificada pelos artigos 70 e 71 da LDB (BRASIL, 1996a), (b) a aceitação da contabilização das despesas educacionais por órgãos diferentes, contrariando o que estabelece a LDB, (c) a oscilação nos critérios de despesas, ora empenhadas, ora liquidadas, ora pagas, (d) a inclusão de restos a pagar de exercícios anteriores pagos no exercício no cálculo dos gastos do exercício (e) a não verificação da destinação dos $60 \%$ do Fundef, se professores, profissionais do magistério ou simplesmente pessoal da educação em exercício no ensino fundamental ou na educação básica, e (f) a falta de uma posição firme sobre a inclusão dos inativos no cálculo das despesas legais em MDE, adotando dois cálculos (com e sem inativos), mas na prática contabilizando os inativos no cálculo do percentual mínimo.

\section{Nota}

1 A pesquisa conta com apoio do CNPq através de Bolsa de Produtividade em Pesquisa.

\section{REFERÊNCIAS}

BRASIL. Constituição da República Federativa do Brasil. Brasília: Senado Federal, 1988. Disponível em: <http://www.planalto.gov.br>. Acesso em: 10 dez. 2010. 
BRASIL. Constituição da República Federativa do Brasil. Brasília: Senado Federal, 1967. Disponível em: <http://www.planalto.gov.br>. Acesso em: 10 fev. 2010.

BRASIL. Emenda Constitucional no 1, de 17 de outubro de 1969. Altera a Constituição Federal de 1967. Diário Oficial da União, Brasília, DF, 20 out. 1969. Republicado com retificaçóes em 30 out. 1969. Disponível em <http://www.planalto.gov.br> Acesso em: 10 dez. 2010.

BRASIL. Emenda Constitucional no 14, de 12 de setembro de 1996. Modifica os arts. 34, 208, 211212 da CF e dá nova redação ao art. 60 do Ato das Disposiçóes Constitucionais Transitórias. Diário Oficial da Uniāo, Brasília, DF, 13 set. 1996c. Disponível em: <http://www.planalto. gov.br/> Acesso em: 10 out. 1996.

BRASIL. Emenda Constitucional no 24, de 1ํ de dezembro de 1983. Estabelece a obrigatoriedade de aplicação anual, pela União, de nunca menos de treze por cento, e pelos Estados, Distrito Federal e Municípios, de, no mínimo, vinte e cinco por cento da renda resultante dos impostos, na manutenção e desenvolvimento do ensino. Diário Oficial da União, Brasília, DF, 5 dez. 1983. Disponível em: <http://www.planalto.gov.br>. Acesso em: $10 \mathrm{dez} .2010$.

BRASIL. Emenda Constitucional no 53, de 19 de dezembro de 2006. Dá nova redação aos arts. 7º , 23, 30, 206, 208, 211 e 212 da Constituição Federal e ao art. 60 do Ato das Disposiçóes Constitucionais Transitórias. Diário Oficial da União, Brasília, DF, 20 dez. 2006. Disponível em: <http://www.planalto.gov.br/> Acesso em: 10 dez. 2010.

BRASIL. Lei no 4.320, de 17 de março de 1964. Estatui Normas Gerais de Direito Financeiro para elaboração e controle dos orçamentos e balanços da União, dos Estados, dos Municípios e do Distrito Federal. Diário Oficial da União, Brasília, DF, 23 mar. 1964. Disponível em: <http://www.planalto.gov.br/>. Acesso em: 10 jan. 2010.

BRASIL. Lei no 7.348, de 24 de julho de 1985. Dispóe sobre a execução do $\$ 4^{\circ}$ do art. 176 da Constituição Federal e dá outras providências. Diário Oficial da União, Brasília, DF, 24 jul. 1985. Disponível em: <http://www.soleis.adv.br/emendacalmon.htm>. Acesso em: 20 out. 2005. 
BRASIL. Lei no 9.394, de 20 de dezembro de 1996. Estabelece as diretrizes e bases da educação nacional. Diário Oficial da União, Brasília, DF, 23 dez. 1996a. Disponível em: <http://www.planalto.gov.br/>. Acesso em: 20 jul. 2010.

BRASIL. Lei no 9.424, de 24 de dezembro de 1996. Dispóe sobre o Fundo de Manutenção e Desenvolvimento do Ensino Fundamental e de Valorização do Magistério, na forma prevista no art. 60, $\$ 7^{\circ}$, do Ato das Disposições Constitucionais Transitórias, e dá outras providências. Diário Oficial da Uniāo, Brasília, DF, 26 dez. 1996b. Disponível em: <http://www.planalto.gov.br/>. Acesso em: 20 jan. 1997. BRASIL. Lei n⿳⺈ 9.766, de 18 de dezembro de 1998. Altera a legislação que rege o salário-educação e dá outras providências. Diário Oficial da União, Brasília, DF, 19 dez. 1998. Disponível em: <http://www.planalto. gov.br>. Acesso em: 10 out. 2005.

BRASIL. Lei no 11.494, de 20 de junho de 2007. Regulamenta o Fundo de Manutenção e Desenvolvimento da Educação Básica e de Valorização dos Profissionais da Educação - FUNDEB, de que trata o art. 60 do Ato das Disposiçóes Constitucionais Transitórias; altera a Lei no 10.195 , de 14 de fevereiro de 2001; revoga dispositivos das Leis $\mathrm{n}^{\mathrm{os}} 9.424$, de 24 de dezembro de 1996, 10.880, de 9 de junho de 2004, e 10.845, de 5 de março de 2004; e dá outras providências. Diário Oficial da União, Brasília, DF, 21 jun. 2007. Disponível em: <http://www.planalto.gov. br/>. Acesso em: 20 jul. 2007.

BRASIL. Ministério da Educação. Conselho Nacional de Educação. Parecer nº CP 26/97, de 2 de dezembro de 1997. Interpreta o financiamento da educação na LDB. Diário Oficial da União, Brasília, DF, p. 40, 18 dez. 1997. Disponível em: <http://portal.mec.gov.br/cne/ arquivos/pdf/PNCP2697.pdf>. Acesso em: 17 jun. 1998.

BRASIL. Ministério da Fazenda. Relatório resumido da execução orçamentária: manual de elaboração n. 1. Brasília, DF, dez. 2001. Disponível em: <http://www.stn.fazenda.gov.br>. Acesso em: $17 \mathrm{dez}$. 2008.

BRASIL. Ministério da Fazenda. Secretaria do Tesouro Nacional. Relatório resumido da execução orçamentária: manual de elaboração n. 7 . 
Brasília, DF, ago. 2007. Disponível em: <http://www.stn.fazenda.gov.br> Acesso em: 17 dez. 2008.

DAVIES, Nicholas. O Fundefe as verbas da educação. São Paulo: Xamã, 2001b.

DAVIES, Nicholas. Tribunais de Contas e educação: quem controla o fiscalizador dos recursos? Brasília: Plano, 2001a.

DAVIES, Nicholas. Verbas da educação: o legal x o real. Niterói: Eduff, 2000.

RIO DE JANEIRO. (Estado). Constituição (1989). Constituição do Estado do Rio de Janeiro de 1989. Rio de Janeiro, 5 out. 1989. Disponível em: <http:/www.alerj.rj.gov.br>. Acesso em: 26 fev. 2010.

SANTA CATARINA. Ofício Tribunal de Contas/Gabinete da Presidência 12938, de 03 novembro 2000. Florianópolis, 2000b.

SANTA CATARINA. Para onde vai o seu dinheiro 5: versão simplificada do parecer prévio do Tribunal de Contas de Santa Catarina: contas do governo: exercício 2006. Florianópolis: TCE, 2007b.

SANTA CATARINA. Para onde vai o seu dinheiro: versão simplificada do parecer prévio do Tribunal de Contas de Santa Catarina: contas do governo: exercício 2002. Florianópolis: TCE, 2003b.

SANTA CATARINA. Parecer prévio sobre as contas prestadas pelo Governador do Estado: exercício 2002. Florianópolis: TCE, 2003a.

SANTA CATARINA. Parecer prévio sobre as contas prestadas pelo Governador do Estado: exercício 2001. Florianópolis: TCE, 2002.

SANTA CATARINA. Parecer prévio sobre as contas prestadas pelo Governador do Estado: exercício 2003. Florianópolis: TCE, 2004. SANTA CATARINA. Parecer prévio sobre as contas prestadas pelo Governador do Estado: exercício 2005. Florianópolis: TCE, 2006.

SANTA CATARINA. Parecer prévio sobre as contas prestadas pelo Governador do Estado: exercício de 2008. Florianópolis: TCE, 2009. Disponível em: <http://www.tce.sc.gov.br>. Acesso em: 10 dez. 2010. 
SANTA CATARINA. Parecer prévio sobre as contas prestadas pelo Governador do Estado: exercício de 2007. Florianópolis: TCE, 2008. Disponível em: <http://www.tce.sc.gov.br>. Acesso em: 10 dez. 2010.

SANTA CATARINA. Parecer prévio sobre as contas prestadas pelo Governador do Estado: exercício 2006. Florianópolis: TCE, 2007a. Disponível em: <http://www.tce.sc.gov.br>. Acesso em: 10 dez. 2010.

SANTA CATARINA. Parecer prévio sobre as contas prestadas pelo Governador do Estado: exercício 2004. Florianópolis: TCE, 2005.

SANTA CATARINA. Parecer prévio sobre as contas prestadas pelo Governador do Estado: exercício 2000: versão simplificada. Florianópolis: TCE, 2001. Disponível em: <http://www.tce.sc.gov.br>. Acesso em: 9 jan. 2011.

SANTA CATARINA. Relatório e Parecer prévio sobre as contas do Governo do Estado: exercício de 1998. Florianópolis: TCE, 1999a.

SANTA CATARINA. Relatório e Parecer prévio sobre as contas do governo do Estado: exercício de 1999. Florianópolis: TCE, 2000a.

SANTA CATARINA. Tribunal de Contas Estadual. Instrução técnica n. 4, de 5 maio 1999. Florianópolis, 1999b. 
The fragile reliability of the audit office of Santa Catarina state in inspecting education financing: the State government failed to invest over $\mathrm{R} \$ 2,1$ billion in education from 1998 to 2008, yet the Audit Office approved the State budgets

\section{Abstract}

This study examined procedures used by the Audit Office of Santa Catarina State in Brazil to evaluate revenue and expenditures earmarked for education, on the basis of its reports on state government accounts from 1998 to 2008. Positive results of the research include (a) identification of the illegality and unconstitutionality of the state government's reduction in taxes earmarked for health and education and (b) a finding of non-compliance with a number of constitutional and legal requirements. In addition, the following negative points are emphasized: (a) the probable confusion between expenses defined as educational in budget law No. 4,320 and expenses defined as maintenance and development of education (MDE) in General Education Law (LDB) No. 9,394, (b) the acceptance of allowing different government agencies to declare educational expenses contrary to the LDB, (c) oscillations in criteria used to define expenses, (d) lack of a
La frágil fiabilidad del tribunal de cuentas de santa catarina en la fiscalización de los recursos para la educación: el gobierno estadual dejó de invertir más de $R \$ 2,1$ billones en educación de 1998 hasta 2008, pero el TC aprobó las cuentas estaduales

\section{Resumen}

Elestudiohaexaminado procedimientos adoptados por el Tribunal de Cuentas de Santa Catarina para la verificación de la receta y de los gastos en educación, con base en sus informes sobre las cuentas estaduales de 1998 a 2008, y llegó a varios resultados, algunos indicados a seguir. Entre los aspectos positivos cabe resaltar (a) el registro de la ilegalidad e inconstitucionalidad del gobierno estadual en sustraer impuestos de la educación y salud a través de mecanismos de desvinculación, como el SEITEC y el Fondo Social y (b) el no cumplimento de varias exigencias constitucionales y legales. Entre los puntos cabe destacar (a) la probable confusión entre gastos en el presupuesto Educación (definida por la Ley 4.320) y en MDE (definida por los artículos 70 y 71 de la LDB), (b) la aceptabilidad de la contabilización de los gastos educacionales por órganos diferentes, contrariando lo que establece la LDB, 
firm position on the inclusion of retired education personnel in the calculation of legal expenses on MDE, adopting 2 procedures (one including and the other excluding this personnel). However, the Audit Office's major weakness is the fact that, despite having found that the State government has not invested the minimum percentage of taxes $(25 \%)$ legally allotted to education, or the $15 \%$ of taxes that should be spent on the 8 years of compulsory elementary education, it has not issued an opinion against the approval of the State accounts, limiting itself to comments and recommendations, which were almost never complied with by the State government. This leads us to question the usefulness of the Audit Office.

Keywords: Education funding. Audit office. Santa Catarina State Brazil. (c) la oscilación en los criterios de gastos, a veces comprometidos, a veces liquidados, a veces pagos, e (d) la falta de una posición firme sobre la inclusión de las personas inactivas en el cálculo de los gastos legales en MDE, adoptando dos cálculos (con o sin los inactivos), pero contabilizando en la práctica los inactivos en el cálculo del porcentual mínimo. La grande debilidad del TC, sin embargo, fue el acto de él, a pesar de haber constatado que el gobierno estadual no aplicó el porcentual mínimo (25\%) de los impuestos en educación, tampoco los $15 \%$ de los impuestos en la enseñanza fundamental o la receta del Fundef, no emitió parecer previo contrario a la aprobación de las cuentas estaduales, limitándose a hacer reservas y recomendaciones, casi nunca cumplidas por el gobierno estadual, lo cual plantea la cuestión de la utilidad del TC.

Palabras clave: Financiamiento de la educación. Tribunal de Cuentas. Santa Catarina.

\section{Nicholas Davies}

E-mail: nicholas@pq.cnpq.br

Recebido em: 25/1/2011

Versáo final recebida em: 28/3/2011

Aprovado em: 1/4/2011 